\title{
MEMBENTUK LOYALITAS PELANGGAN
}

\author{
Otong Karyono ${ }^{1)}$, Jefry Romdonny ${ }^{2)}$ \\ Program Studi Teknik Industri, Fakutas Teknik, Universitas Majalengka ${ }^{1)}$ \\ e-mail : karyono.otong@gmail.com \\ Program Studi Prodi Manajemen, STIE STMY Majalengka ${ }^{2)}$ \\ e-mail : romdonnyjefry@gmail.com
}

\begin{abstract}
Marketing mix and quality of banking services performed by the Bank in this decade is crucial in improving satisfaction that will contribute to increased customer loyalty. This is due to current banking conditions are faced on a variety of phenomena that have entered the realm of competition, especially in an increasingly competitive due to the emergence of financial institutions whether in the banking and non-banks that offer services such as savings and loans banks. This study aims to identify, assess and analyze the influence of the marketing mix and quality of banking services to the satisfaction and the impact on customer loyalty. Locus of research conducted in PD. BPR LPK.
\end{abstract}

Keywords: marketing mix of services, Quality Service, Customer Satisfaction and Loyalty

\section{PENDAHULUAN}

Kesetiaan pelanggan merupakan determinan utama dalam kinerja keuangan jangka panjang. Secara signifikan terlihat bahwa tingginya kesetiaan pelanggan ternyata mampu menaikan laba perusahaan (McDougall, 2000:392). Kondisi ini menyatakan pemeliharaan kesetiaan pada pelanggan merupakan faktor terpenting untuk meningkatkan kinerja laba dari suatu perusahaan, sehingga perolehan pelanggan yang loyal merupakan tujuan akhir dari perusahaan. Apabila dikaitkan dengan industri perbankan sebagai industri jasa yang perannya semakin meningkat, maka pemeliharaan nasabah merupakan prioritas perbankan dalam meraih keunggulan bersaing. Kotler \& Keller (2009:41) berpendapat bahwa upaya pencapaian kesetiaan pelanggan merupakan tujuan pemasaran pada milenium mendatang. Untuk itulah perusahaan dituntut untuk mampu memupukkeunggulan bersaingnya, masing-masing melalui upaya yang kreatif, inovatif serta efisien, sehingga menjadi pilihan dari banyak pelanggan yang pada gilirannya nanti diharapkan loyal (Javalgi, 1997:165).

Konsumen yang loyal merupakan aset tak ternilai bagi perusahaan, karena karakteristik dari konsumen yang loyal menurut Griffin (2002:31) antara lain : (1) melakukan pembelian ulang secara teratur (repeat purchase), (2) membeli diluar lini poduk jasa, (3) mengajak orang lain (referrals), (4) menunjukkan kekebalan dari tarikan persaingan (tidak mudah terpengaruh oleh tarikan persaingan produk sejenis lainnya/retention). Dalam perkembangannya, tuntutan nasabah saat ini menjadi sangat krusial mengingat terjadinya kemajuan diberbagai bidang terutama dalam bidang teknologi dan informasi yang mengakibatkan nasabah menjadi selektif dalam memilih produk dan jasa. Tidak terpenuhinya tuntutan nasabahakan jasa kredit oleh pihak bank, menjadi suatu peluang bagi bank lain untuk memenuhi tuntutan nasabah akan jasa kredit dengan nilai yang superior yang diterima oleh pelanggan/nasabah. Pemenuhan tuntutan oleh bank lain merupakan salah satu potensi pesaing yang harus dicermati apabila sebuah bank tidak ingin kehilangan nasabahnya. Menurut Clottey, et.al (2008) menyatakan bahwa faktor untuk mempertahankan nasabah dan meningkatkan keunggulan bersaing dengan meningkatkan pelayanan sehingga akan tercipta kepuasan bagi pelanggan (Cohen, et.al.,2006; Tsiotsou, 2005; Roos et.al, 2006).

Kualitas pelayanan yang mencakup harapan tentang kehandalan (Reliability), daya tanggap (Responsibility), jaminan (Assurance), empati (Empathy), dan bukti langsung (Tangible).(Parasuraman dalam Tjiptono dan Chandra, 2005:15). Sedangkan hasil riset dari Bahia dan Nantel (2000) mengembangkan konsep kualitas pelayanan menjadi Bank Service Quality (BSQ) dalam menilai pelayanan pada sebuah bank. Bauran pemasaran jasa dan kualitas pelayanan diharapkanakan meningkatkan kepuasan pelanggan yang pada akhirnya loyalitas nasabah akan tercipta. Menurut hasil penelitian Ladhari dan Morales (2007) menyatakan bahwa penerimaan kualitas pelayanan dan penermaan nilai bagi pelanggan akan berpengaruh terhadap loyalitas pelanggan. 
Jurnal J-Ensitec: Vol 04|No. 01, November 2017

Disamping itu, bauran pemasaran jasa merupakan salah satu alat pemasaran jasa yang utama dalam kondisi perbankan saat ini, karena program bauran pemasaran jasa memainkan peranan yang sangat penting sebagai bagian dari strategi dan kebijakan perbankan untuk mewujudkan kepuasan nasabah yang pada akhirnya diharapkan akan meningkatkan kesetiaan nasabah.

\section{METODE PENELITIAN}

Penelitian ini bersifat deskriptif dan verifikatif. Metode yang digunakan dalam penelitian ini adalah metode survei. Dalam metode penelitian survei, data dikumpulkan dari sampel atas populasi dan menggunakan kuesioner sebagai alat pengumpulan data yang pokok (Singarimbun dan Effendi, 2005). Sumber data pada penelitian ini adalah data primer dan sekunder. Cara pengumpulan data dilakukan melalui studi kepustakaan, studi lapangan, wawancara, observasi dan kuesioner. Populasi pada penelitian iniadalah PD. BPR LPK di Kabupaten Majalengka yang berjumlah sebanyak 51 unit sesuai dengan Peraturan Daerah Provinsi Jawa Barat Nomor 14 Tahun 2006, yang tersebar pada setiap Kabupaten dan Kota yang berada di Kabupaten Majalengka rat. Sampel dalam penelitian ini adalah para nasabah pelaku bisnis PD. BPR LPK Kabupaten Majalengka, metode yang digunakan dalam menentukan sampel menggunakan teknik cluster sampling area (pemilihan sampel berdasarkan kelompok wilayah) dengan pemilihan subjek ditentukan secara proposional. Berdasarkan rumus slovin maka jumlah sampel minimal yang diambil adalah sebanyak 250 nasabah yang tersebar di PD. BPR LPK Kabupaten Majalengka.

Analisis data yang dilakukan terhadap data primer dari lapangan dibagi dalam dua jenis yaitu: bagian pertama, analisis data deskriptif dalam bentuk gambar diagram selanjutnya dibahas dan konfrontir dengan konsep-konsep yang telah ada apakah sesuai dengan teori, menambah teori yang ada atau bertentangan dengan teori yang ada. Bagian kedua, analisis data dengan analisis verifikatif, yaitu dengan menggunakan model structural equation modeling (SEM).

\section{HASIL PENELITIAN}

\section{a. Deskripsi Variabel Bauran Pemasaran}

Tabel di bawah ini menunjukkan nilai rata-rata dan standar deviasi dan kriteria jawaban responden, dimana kriteria responden berada pada kriteria jawaban dari kurang baik sampai dengan sangat baik.

Tabel 1 Deskripsi Variabel Bauran Pemasaran

\begin{tabular}{|c|c|c|}
\hline Dimensi & $\begin{array}{c}\text { Rentang } \\
\text { Nilai }\end{array}$ & $\begin{array}{c}\text { Kriteria } \\
\text { Jawaban }\end{array}$ \\
\hline
\end{tabular}

\begin{tabular}{|c|c|c|}
\hline $\begin{array}{l}\text { Produk } \\
\text { (Product) }\end{array}$ & $\begin{array}{c}2,649 \mathrm{~s} / \mathrm{d} \\
4,501\end{array}$ & $\begin{array}{c}\text { Kurang baik- } \\
\text { sangat baik }\end{array}$ \\
\hline Harga (Price) & $\begin{array}{c}2,514 \mathrm{~s} / \mathrm{d} \\
4,266\end{array}$ & $\begin{array}{l}\text { Kurang baik- } \\
\text { sangat baik }\end{array}$ \\
\hline Tempat (Place) & $\begin{array}{c}2,286 \mathrm{~s} / \mathrm{d} \\
4,131\end{array}$ & $\begin{array}{l}\text { Kurang baik- } \\
\text { sangat baik }\end{array}$ \\
\hline $\begin{array}{l}\text { Promosi } \\
\text { (Promotion) }\end{array}$ & $\begin{array}{c}2,437 \mathrm{~s} / \mathrm{d} \\
4,311\end{array}$ & $\begin{array}{l}\text { Kurang baik- } \\
\text { sangat baik }\end{array}$ \\
\hline Orang (People) & $\begin{array}{c}2,551 \mathrm{~s} / \mathrm{d} \\
4,277\end{array}$ & $\begin{array}{l}\text { Kurang baik- } \\
\text { sangat baik }\end{array}$ \\
\hline $\begin{array}{l}\text { Proses } \\
\text { (Process) }\end{array}$ & $\begin{array}{c}2,543 \mathrm{~s} / \mathrm{d} \\
4,325\end{array}$ & $\begin{array}{l}\text { Kurang baik- } \\
\text { sangat baik }\end{array}$ \\
\hline $\begin{array}{l}\text { Tampilan Fisik } \\
\text { (Physical } \\
\text { Evidence) }\end{array}$ & $\begin{array}{c}2,548 \\
\text { s/d } \\
4,256 \\
\end{array}$ & $\begin{array}{l}\text { Kurang baik- } \\
\text { sangat baik }\end{array}$ \\
\hline Rata-rata & $\begin{array}{c}2,504 \\
\text { s/d 4,295 }\end{array}$ & $\begin{array}{c}\text { Kurang baik- } \\
\text { sangat baik }\end{array}$ \\
\hline
\end{tabular}

Sumber : Data diolah, 2016

Nilai rata-rata bauran pemasaran jasa sebesar 3,399 dan nilai standar deviasi sebesar 0,895 sehingga interval jawaban responden berada pada rentang 2,504 dan 4,295 yang mengindikasikan responden menjawab dari kurang baik sampai sangat baik. Namun, dilihat dari keseluruhan analisis terhadap variabel bauran pemasaran sebagian besar responden mempersepsikan dengan baik, dan hanya sebagian kecil responden mempersepsikan kurang baik. Oleh karena itu, hasil terhadap analisis ini dapat disimpulkan bahwa kondisi bauran pemasaran berada pada kriteria cukup baik.

\section{b. Deskripsi Variabel Kualitas pelayanan jasa perbankan}

Tabel di bawah ini menunjukkan nilai rata-rata dan standar deviasi dan kriteria jawaban responden, dimana kriteria responden berada pada kriteria jawab dari kurang baik sampai dengan sangat baik.Untuk lebih jelasnya dapat dilihat pada tabel di bawah ini.

Tabel 2 Deskripsi Kualitas Pelayanan Jasa Perbankan

\begin{tabular}{|c|c|c|}
\hline Dimensi & $\begin{array}{c}\text { Rentang } \\
\text { Nilai }\end{array}$ & $\begin{array}{l}\text { Kriteria } \\
\text { Jawaban }\end{array}$ \\
\hline $\begin{array}{l}\text { Dimensi Akses } \\
\text { (Acces) }\end{array}$ & $\begin{array}{c}2,959 \mathrm{~s} / \mathrm{d} \\
4,771\end{array}$ & $\begin{array}{c}\text { Kurang baik- } \\
\text { sangat baik }\end{array}$ \\
\hline $\begin{array}{l}\text { Dimensi } \\
\text { Kredibilitas dan } \\
\text { Reputasi }\end{array}$ & $\begin{array}{c}3,134 \mathrm{~s} / \mathrm{d} \\
4,244\end{array}$ & $\begin{array}{l}\text { Kurang baik- } \\
\text { sangat baik }\end{array}$ \\
\hline $\begin{array}{l}\text { Dimensi } \\
\text { Kehandalan }\end{array}$ & $\begin{array}{c}2,5225 \mathrm{~s} / \mathrm{d} \\
4,786\end{array}$ & $\begin{array}{l}\text { Kurang baik- } \\
\text { sangat baik }\end{array}$ \\
\hline $\begin{array}{l}\text { Dimensi Daya } \\
\text { Tanggap }\end{array}$ & $\begin{array}{c}3,053 \mathrm{~s} / \mathrm{d} \\
4,395\end{array}$ & $\begin{array}{l}\text { Kurang baik- } \\
\text { sangat baik }\end{array}$ \\
\hline $\begin{array}{l}\text { Dimensi Efektifitas } \\
\text { dan Jaminan }\end{array}$ & $\begin{array}{c}3,187 \mathrm{~s} / \mathrm{d} \\
4,629\end{array}$ & $\begin{array}{l}\text { Kurang baik- } \\
\text { sangat baik }\end{array}$ \\
\hline \multirow[t]{2}{*}{$\begin{array}{l}\text { Dimensi Fasilitas } \\
\text { dan peralatan }\end{array}$} & $\begin{array}{c}3,225 \mathrm{~s} / \mathrm{d} \\
4,535\end{array}$ & $\begin{array}{c}\text { Kurang baik- } \\
\text { sangat baik }\end{array}$ \\
\hline & $\begin{array}{c}3,013 \mathrm{~s} / \mathrm{d} \\
4,560\end{array}$ & $\begin{array}{l}\text { Kurang baik- } \\
\text { sangat baik }\end{array}$ \\
\hline
\end{tabular}

Sumber : Data diolah, 2016 
Jurnal J-Ensitec: Vol 04|No. 01, November 2017

Nilai rata-rata kualitas pelayanan jasa perbankan adalah 3,786 dan nilai standar deviasi adalah 0,655, sehingga interval jawaban responden berada pada rentang 3,013 dan 4,560 yang mengindikasikan responden menjawab dari kurang baik sampai sangat baik. Namun, dilihat dari keseluruhan analisis terhadap variabel kualitas pelayanan jasa perbankan sebagian besar responden mempersepsikan dengan baik, dan hanya sebagian kecil responden mempersepsikan kurang baik. Oleh karena itu, hasil terhadap analisis ini dapat disimpulkan bahwa kondisi kualitas pelayanan jasa perbankan nasabah berada pada kriteria cukup baik.

\section{c. Deskripsi Variabel Kepuasan Nasabah Pelaku Bisnis}

Tabel di bawah ini menunjukkan nilai rata-rata dan standar deviasi dan kriteria jawaban responden, dapat dilihat sebagai berikut.

Tabel 3 Deskripsi Variabel Kepuasan Nasabah Pelaku Bisnis

\begin{tabular}{|c|c|c|}
\hline Dimensi & $\begin{array}{l}\text { Rentang } \\
\text { Nilai }\end{array}$ & Kriteria Jawaban \\
\hline $\begin{array}{l}\text { Kemudahan dan } \\
\text { kenyamanan }\end{array}$ & $\begin{array}{c}2,548 \mathrm{~s} / \mathrm{d} \\
4,484\end{array}$ & $\begin{array}{c}\text { Kurang baik- } \\
\text { sangat baik }\end{array}$ \\
\hline $\begin{array}{l}\text { Nilai nasabah } \\
\text { pelaku bisnis }\end{array}$ & $\begin{array}{c}3,573 \mathrm{~s} / \mathrm{d} \\
3,721\end{array}$ & $\begin{array}{l}\text { Kurang baik- } \\
\text { sangat baik }\end{array}$ \\
\hline $\begin{array}{l}\text { Keterbukaan } \\
\text { Informasi }\end{array}$ & $\begin{array}{c}3,424 \mathrm{~s} / \mathrm{d} \\
3,732\end{array}$ & $\begin{array}{l}\text { Kurang baik- } \\
\text { sangat baik }\end{array}$ \\
\hline Komunikasi & $\begin{array}{c}3,412 \mathrm{~s} / \mathrm{d} \\
3,794\end{array}$ & $\begin{array}{l}\text { Kurang baik- } \\
\text { sangat baik }\end{array}$ \\
\hline $\begin{array}{l}\text { Program } \\
\text { Undian }\end{array}$ & $\begin{array}{c}3,251 \mathrm{~s} / \mathrm{d} \\
3,675\end{array}$ & $\begin{array}{l}\text { Kurang baik- } \\
\text { sangat baik }\end{array}$ \\
\hline $\begin{array}{l}\text { Novelty } \\
\text { (Kejutan) }\end{array}$ & $\begin{array}{c}3,168 \mathrm{~s} / \mathrm{d} \\
3,646\end{array}$ & $\begin{array}{l}\text { Kurang baik- } \\
\text { sangat baik }\end{array}$ \\
\hline Rata-rata & $\begin{array}{c}3,229 \mathrm{~s} / \mathrm{d} \\
3,842\end{array}$ & $\begin{array}{l}\text { Kurang baik- } \\
\text { sangat baik }\end{array}$ \\
\hline
\end{tabular}

Sumber : Data diolah, 2016

Nilai rata-rata kepuasan jawaban sebesar 3,536 dan nilai standar deviasi sebesar 0,306, sehingga rentang jawaban responden berada pada kisaran 3,229 sampai dengan 3,842. Rentang tersebut mengindikasi jawaban dari mulai kurang baik sampai dengan sangat baik.Namun,jika dilihat dari hasil analisis secara spesifisik yang terdapat pada Tabel 4.64 diperoleh indikator-indikator yang telah memenuhi harapan nasabah dan indicator-indikator yang masih di bawah harapan nasabah.

\section{d. Deskripsi Variabel Loyalitas Nasabah pelaku bisnis}

Tabel di bawah ini menunjukkan nilai rata-rata dan standar deviasi dan kriteria jawaban responden. Untuk lebih jelasnya dapat dilihat pada tabel di bawah ini.
Tabel 4 Deskripsi Variabel Loyalitas Nasabah Pelaku Bisnis

\begin{tabular}{|l|c|c|}
\hline \multicolumn{1}{|c|}{ Dimensi } & $\begin{array}{c}\text { Rentang } \\
\text { Nilai }\end{array}$ & $\begin{array}{c}\text { Kriteria } \\
\text { Jawaban }\end{array}$ \\
\hline Pembelian Berulang & $\begin{array}{c}2,736 \\
\mathrm{~s} / \mathrm{d} \\
4,002\end{array}$ & $\begin{array}{c}\text { Kurang } \\
\text { baik-sangat } \\
\text { baik }\end{array}$ \\
\hline $\begin{array}{l}\text { Rekomendasi } \\
\text { kepada konsumen } \\
\text { lain }\end{array}$ & $\begin{array}{c}2,483 \\
\mathrm{~s} / \mathrm{d} \\
4,335\end{array}$ & $\begin{array}{c}\text { Kurang } \\
\text { baik-sangat } \\
\text { baik }\end{array}$ \\
\hline $\begin{array}{l}\text { Kesediaan berbagi } \\
\text { informasi }\end{array}$ & $\begin{array}{c}2,898 \\
\mathrm{~s} / \mathrm{d}\end{array}$ & $\begin{array}{c}\text { Kurang } \\
\text { baik-sangat } \\
\text { baik }\end{array}$ \\
\hline $\begin{array}{l}\text { Ketahanan daya } \\
\text { tarik pesaing }\end{array}$ & $\begin{array}{c}2,312 \\
4,572 \mathrm{~s} / \mathrm{d}\end{array}$ & $\begin{array}{c}\text { Kurang } \\
\text { baik-sangat } \\
\text { baik }\end{array}$ \\
\hline $\begin{array}{l}\text { Penggunaan jasa } \\
\text { layanan lainnya }\end{array}$ & $3,000 \mathrm{~s} / \mathrm{d}$ \\
4,628 & $\begin{array}{c}\text { Kurang } \\
\text { baik-sangat } \\
\text { baik }\end{array}$ \\
\hline Rata-rata & $2,798 \mathrm{~s} / \mathrm{d}$ & $\begin{array}{c}\text { Kurang } \\
\text { baik-sangat } \\
\text { baik }\end{array}$ \\
\hline
\end{tabular}

Sumber : Data diolah, 2016

Kesimpulan dari analisis terhadap loyalitas nasabah pelaku bisnis, diperoleh rentang jawaban berada di antara 2,798 sampai dengan 4,357. Rentang tersebut mengindikasikan bahwa responden mempersepsikan kurang baik sampai dengan sangat baik. Namun, dilihat dari keseluruhan analisis terhadap variabel loyalitas sebagian besar responden mempersepsikan dengan baik, dan hanya sebagian kecil responden mempersepsikan kurang baik. Oleh karena itu, hasil terhadap analisis ini dapat disimpulkan bahwa kondisi loyalitas nasabah berada pada kriteria cukup baik.

\section{e. Analisis Structural Equation Modelling (SEM)}

Dalam analisis SEM terhadap model struktural untuk mengetahui pengaruh bauran pemasaran dan kualitas pelayanan jasa perbankan terhadap kepuasan serta dampaknya pada loyalitas nasabah Pada PD. BPR LPK Kabupaten Majalengka. Uji kecocokan model (Goodness-of-fits) sangat berguna untuk mengetahui kesesuaian model SEM yang dibentuk. Dalam tabel berikut ini disajikan beberapa indeks yang umumnya dipakai untuk menentukan kecocokan model dalam analisis model persamaan terstruktur.

Tabel 5 Uji Kecocokan Model SEM

\begin{tabular}{|l|l|l|l|}
\hline $\begin{array}{l}\text { Indeks } \\
\text { kecocokan }\end{array}$ & Nilai & $\begin{array}{l}\text { Cut off } \\
\text { value }\end{array}$ & Kesimpulan \\
\hline Chi-kuadrat & 143,25 & $\begin{array}{l}\text { diharapkan } \\
\text { kecil }\end{array}$ & $\begin{array}{l}\text { Tolak } \mathrm{H}_{0}, \\
\text { model } \\
\text { kurang baik }\end{array}$ \\
\hline P-value & 0,000 & $<0,05$ & $\begin{array}{l}\text { Tolak } \mathrm{H}_{0}, \\
\text { model } \\
\text { kurang baik }\end{array}$ \\
\hline RMSEA & 0,055 & $<0,08$ & Terima $\mathrm{H}_{0}$, \\
\hline
\end{tabular}

Computer Science | Industrial Engineering | Mechanic Engineering |Civil Engineering 


\begin{tabular}{|l|l|l|l|}
\hline $\begin{array}{l}\text { Standarized } \\
\text { RMR }\end{array}$ & 0,048 & $<0,05$ & $\begin{array}{l}\text { model baik } \\
\text { morima } \mathrm{H}_{0}, \\
\text { model baik }\end{array}$ \\
\hline GFI & 0,933 & $>0,90$ & $\begin{array}{l}\text { Terima } \mathrm{H}_{0}, \\
\text { model baik }\end{array}$ \\
\hline NFI & 0,956 & $>0,90$ & $\begin{array}{l}\text { Terima } \mathrm{H}_{0}, \\
\text { model baik }\end{array}$ \\
\hline NNFI & 0,971 & $>0,90$ & $\begin{array}{l}\text { Terima } \mathrm{H}_{0}, \\
\text { model baik }\end{array}$ \\
\hline CFI & 0,977 & $>0,90$ & $\begin{array}{l}\text { Terima } \mathrm{H}_{0}, \\
\text { model baik }\end{array}$ \\
\hline
\end{tabular}

Sumber : Data diolah, 2016

Dari sembilan indeks uji kecocokan model, hanya nilai Chi-kuadrat dan P-valuenya saja yang menyatakan model kurang baik, sedangkan indeks lainnya seperti GFI, AGFI, NFI, NNFI dan CFI mengindikasikan bagwa model sudah baik. Berdasarkan indeks kecocokannya model SEM yang dibentuk sudah menggambarkan lebih dari $90 \%$ modelnya dikatakan baik. Dengan demikian model ini akan digunakan untuk menjawab hipotesis dalam penelitian. Gambar 1 berikut merupakan hasil analisis SEM untuk model teoritis (standardized solution).

Tabel berikut ini merupakan pengujian model terstuktur Bauran pemasaran dan kualitas pelayanan jasa perbankan terhadap kepuasan serta dampaknya pada loyalitas nasabah.

Tabel 6 Koefisien Regresi Model SEM

\begin{tabular}{|c|c|c|c|c|c|l|}
\hline $\begin{array}{l}\text { Var } \\
\text { endo- } \\
\text { gen }\end{array}$ & $\begin{array}{l}\text { Var } \\
\text { ekso- } \\
\text { gen }\end{array}$ & $\begin{array}{l}\text { Para- } \\
\text { meter }\end{array}$ & $\begin{array}{l}\text { Para- } \\
\text { meter } \\
\text { dibekukan }\end{array}$ & $\begin{array}{l}\text { Simp. } \\
\text { baku }\end{array}$ & $\mathbf{T}_{\text {hitung }}$ & Kes \\
\hline Y & X1 & 0,50 & 0,501 & 0,0594 & 8,436 & Signifikan \\
\hline Y & X2 & 0,64 & 0,643 & 0,1133 & 9,765 & Signifikan \\
\hline Z & Y & 0,86 & 0,863 & 0,0245 & 6,995 & Signifikan \\
\hline
\end{tabular}

Sumber : Data diolah, 2016

Berdasarkan Tabel 6 di atas diketahui bahwa bauran pemasaran dan kualitas pelayanan jasa perbankan memberikan pengaruh terhadap kepuasan nasabah, masing-masing ditunjukkan oleh nilai $\mathrm{T}_{\text {hitung }}$ sebesar 8,436 dan 9,765 ( $\left.\mathrm{T}_{\text {hitung }}>1,96\right)$. Begitupun dengan kepuasan nasabah memberikan pengaruh yang signifikan terhadap loyalitas nasabah, karena memiliki nilai statistik uji $\mathrm{T}_{\text {hitung }}=6,995 \mathrm{yang}$ lebih besar dari 1,96. Pengaruh secara bersama-sama (simultan) pengaruh bauran pemasaran $\left(\xi_{1}\right)$ dan Kualitas pelayanan jasa perbankan $\left(\xi_{2}\right)$ terhadap kepuasan nasabah pelaku bisnis $\left(\dot{\eta}_{1}\right)$. Keseluruhan data yang mempengaruhi langsung dan tidak langsung tersebut ditunjukkan pada tabel sebagai berikut :
Tabel 7 Pengaruh Langsung dan Tidak Langsung Bauran Pemasaran dan Kualitas pelayanan jasa perbankan terhadap Kepuasan Nasabah Pelaku Bisnis

\begin{tabular}{|l|c|l|c|}
\hline & $\begin{array}{l}\text { Pengaruh } \\
\text { langsung }\end{array}$ & $\begin{array}{l}\text { Pengaruh tidak } \\
\text { langsung }\end{array}$ & $\begin{array}{l}\text { Total } \\
\text { Pengaruh }\end{array}$ \\
\hline $\begin{array}{l}\text { Bauran } \\
\text { Pemasaran }\end{array}$ & $25,100 \%$ & $\begin{array}{l}\text { Melalui Kualitas } \\
\text { pelayanan jasa } \\
\text { perbankan(1,159\%) }\end{array}$ & $26,259 \%$ \\
\hline $\begin{array}{l}\text { Kualitas } \\
\text { pelayanan } \\
\text { jasa } \\
\text { perbankan }\end{array}$ & $\begin{array}{l}\text { Melalui Bauran } \\
\text { Pemasaran (1,159\%) }\end{array}$ & $42,503 \%$ \\
\hline \multirow{3}{*}{$\begin{array}{l}\text { Total pengaruh langsung dan tidak } \\
\text { langsung }\end{array}$} & $68,762 \%$ \\
\cline { 2 - 4 } & \multicolumn{2}{|l|}{ Variabel sisa (Epsilon) } & $31,238 \%$ \\
\cline { 2 - 4 } & Nilai sig. & 0,000 \\
\hline
\end{tabular}

Sumber : Data diolah, 2016

Melalui analisis data di atas dapat diketahui bahwa besarnya total pengaruh secara simultan dari variabel bauran pemasaran dan Kualitas pelayanan jasa perbankansebesar 68,762\%. Hal ini menunjukkan bahwa bauran pemasaran dan Kualitas pelayanan jasa perbankancukup tinggi dalam mempengaruhi kepuasan nasabah pelaku bisnis. Sedangkan sisanya 31,238\% diterangkan oleh variabel-variabel lain di luar model yang mempengaruhi kepuasan nasabah pelaku bisnis. Variabel yang tidak diteliti atau diolah dalam model yang dilambangkan dengan notasi $\zeta$ (zeta) yaitu sebesar 31,238\%.

Berdasarkan Tabel 7 di atas menunjukkan bahwa pengaruh langsung dari variabel bauran pemasaran terhadap kepuasan nasabah pelaku bisnis sebesar $(0,501)^{2}$ atau $25,100 \%$.Sedangkan pengaruh secara tidak langsung dari variabel bauran pemasaran terhadap kepuasan nasabah pelaku bisnis melalui kualitas pelayanan jasa perbankansebesar $1,159 \%$.Jadi, total pengaruh bauran pemasaran terhadap kepuasan nasabah pelaku bisnis adalah sebesar 26,259\%. Sebagaimana analisis terhadap bauran pemasaran,maka pengaruh langsung kualitas pelayanan jasa perbankanterhadap kepuasan nasabah pelaku bisnis adalah 0,643 atau 41,344\%.Sedangkan pengaruh secara tidak langsung dari kualitas pelayanan jasa perbankanterhadap kepuasan nasabah pelaku bisnis melalui bauran pemasaran sebesar $1,159 \%$.Jadi, total pengaruh variabel kualitas pelayanan jasa perbankan terhadap kepuasan nasabah pelaku bisnis adalah sebesar 42,503\%.Dengan demikian dapat diinterprestasikan bahwa kualitas pelayanan jasa perbankan mempunyai pengaruh yang signifikan terhadap kepuasan nasabah pelaku bisnis. Dari tabel 7 di atas dapat diketahui bahwa nilai $\mathrm{R}^{2}$ sebesar 0,743 . Hal ini mengindikasikan bahwa loyalitas nasabah pelaku bisnis dapat dijelaskan oleh variabel kepuasan 
nasabah.Hal tersebut telah menggambarkan bahwa secara keseluruhan mampu memberikan kontribusi menjelaskan yang cukup baik. Total Pengaruh kepuasan nasabah terhadap loyalitas nasabah pelaku bisnis adalah $\mathrm{R}^{2}=\left(\rho^{2} \times 100 \%\right)$, maka $\left(0,863^{2} \times 100\right)=$ $74,476 \%$; menunjukkan bahwa variabel kepuasan dapat mendorong terhadap peningkatan loyalitas pelanggan.

\section{KESIMPULAN}

Kinerja Bauran pemasaran secara umum telah sesuai dengan tuntutan nasabah PD. BPR LPK di Kabupaten Majalengka. Hal ini terlihat dari hasil analisis bahwa bauran pemasaran secara umum dikategorikan cukup baik menurut persepsi responden. Adapun dimensi yang paling tinggi penilaiannya pada variabel bauran pemasaran adalah dimensi produk terutama pada indikator kualitas dari produk jasa kredit yang dikeluarkan oleh pihak Bank. Kualitas pelayanan jasa perbankan secara umum telah sesuai dengan tuntutan nasabah PD. BPR LPK Kabupaten Majalengka. Hal ini terlihat dari hasil analisis bahwa kualitas pelayanan jasa perbankan secara umum dikategorikan baik menurut persepsi responden. Adapun dimensi yang paling tinggi penilaiannya pada variabel kualitas pelayanan adalah dimensi efektivitas dan jaminan, sedangkan untuk indikator kemudahan dalam persyaratan kredit merupakan indikator tertinggi. Hasil temuan terhadap kepuasan nasabah pada PD. BPR LPK Kabupaten Majalengka, sebagian besar masih terdapat kesenjangan antara harapan dan kinerja (kenyataan). Untuk kepuasan nasabah yang sudah sesuai dengan harapan nasabah diantaranya kenyamanan dalam pembayaran, Kesesuaian antara korbanan dengan manfaat, Kemampuan dalam membuat program baru dan manfaat program baru. Hasil temuan terhadap loyalitas nasabah pada PD. BPR LPK Kabupaten Majalengka, baru mencapai tahap repeat customer dan Client. Posisi tersebut masih rentannya retensi nasabah untuk berpindah. Namun demikian, posisi ini juga mengindikasikan bahwa pihak nasabah sedang menjalin relasi (mitra) dengan pihak PD.BPR LPK. Dari penilaian yang didasarkan pada hasil analisis ditemukan bahwa indikator yang memiliki nilai tertinggi yaitu pada indikator kesediaan menggunakan produk jasa kembali, pemberian kesan positif kepada pihak manajemen Bank, kesediaan untuk memberikan informasi kepada orang lain, penghargaan bank kepada nasabah pelaku bisnis dan manfaat produk jasa lainnya pada PD. BPR LPK.

Bauran pemasaran dan kualitas pelayanan jasa perbankan berpengaruh positif dan signifikan terhadap kepuasan nasabah secara simultan.
Semakin tinggi penilaan nasabah terhadap bauran pemasaran jasa dan kualitas pelayanan, maka semakin besar pengaruhnya dalam meningkatkan kepuasan nasabah. Bauran pemasaran berpengaruh positif dan signifikan terhadap kepuasan nasabah. Semakin tinggi penilaan nasabah terhadap bauran pemasaran, maka semakin besar pengaruhnya dalam meningkatkan kepuasan nasabah. Kualitas pelayanan jasa perbankan berpengaruh positif dan signifikan terhadap kepuasan nasabah. Semakin tinggi penilaan nasabah terhadap kualitas pelayanan jasa perbankan, maka semakin besar pengaruhnya dalam meningkatkan kepuasan nasabah. Pada penelitian ini ditemukan juga pengaruh kualitas pelayanan terhadap kepuasan nasabah lebih besar dari bauran pemasaran jasa terhadap kepuasan nasabah. Kepuasan nasabah mempengaruhi loyalitas nasabah secara signifikan. Artinya semakin tinggi nilai kepuasan yang dirasakan nasabah maka semakin besar kepuasan nasabah terhadap bank dan secara signifikan akan mempengaruhi loyalitas nasabah pada bank.

\section{REFERENSI}

Bahia, Kamilia dan Nantel, Jacques, 2000, A reliable and valid measurement scale for the perceived service quality of banks, International Journal of Bank Marketing, No.2, Vol.18, page.84-91.

Griffin, Jill. 2005. Customer Loyality. Menumbuhkan dan Mempertahankan Kesetiaan Pelanggan. Edisi Revisi dan Terbaru. Alih Bahasa Dr.Dwi Kartini Yahya. Jakarta : Erlangga.

Griffin, Jill. 2002. Customer Loyality. Edisi Bahasa Indonesia. Alih Bahasa Dwi Kartini Yahya. Jakarta : Erlangga.

Clottey, Toyin A., David A. Collier and Michael Stodnick. 2008. Drivers Of Customer Loyalty In A Retail Store Environment. Journal of Service Science - Third Quarter 2008. Volume 1, Number 1.

Cohen, David., Christopher Gan., Hua Hwa Au Yong and Esther Choong. 2006. Customer Satisfaction: a Study of Bank Customer Retention in New Zealand. Commerce Division. Discussion Paper No. 109.

Cronin , Joseph J., Michael K. Brady., and G. Thomas M. Hult.2000. Assessing the Effect of Quality, Value, and Customer Satisfaction on Consumer Behavioral Intentions in Service Environments. Journal of Retailing, Vol.76, No.2,pp. `93-218.

Duff, Angus, Xin Guo dan Mario Hair. 2008. Service quality measurement in the Chinese corporate banking market. International 
Journal of Bank Marketing Vol. 26 No. 5, 2008 pp. 305-327 q Emerald Group Publishing Limited 0265-2323 DOI 10.1108/02652320810894389.

Javalgi, Rajshekhar G. dan Moberg, C.R., 1997. Service Loyalty: Implication For Service Providers. The Journal Of Service Marketing, 11(3), 165-179.

Johnston, R. 1997. Identifying the critical determinants of service quality in retail banking: importance and effects. The International Journal of Bank Marketing , 15(4), 111-119.

Kirom, Bahrul. 2009. Mengukur Kinerja Pelayanan dan Kepuasan Konsumen. Reka Cipta : Bandung.

Kottler, Philip and Kevin Lane Keller. 2009. Marketing Management. 13th. edition. New Jersey : Prentice Hall.

Ladhari, Riadh and Miguel Morales. 2007. Perceived service quality, perceived value and recommendation $A$ study among Canadian public library users. Library Management Vol. 29 No. 4/5, 2008 pp. 352366q Emerald Group Publishing Limited 0143-5124

DOI 10.1108/01435120810869129.

Mc Dougall H. G., Levesque T, 2000, Customer Satisfaction with Service: putting Perceived Value into the Equation, Journal of Service Marketing, Vol. 15 No. 5. Pp 392-410.

Othman AQ and Owen L, 2002. The multidimensionality of Carter Model to measure customer service quality $(S Q)$ in Islamic banking industry: A study in Kuwait Finance House. International Journal of Islamic Financial Services , 3(4), pp 1-12.
Parasuraman,A.;Berry,Leonard L.;Zeithaml,Valarie A.1988. SERVQUAL: A Multiple-Item Scale For Measuring Consumer Perceptions of Service Quality, Journal of Retailing, 1988, $64,1,12-40$.

Roberts et.al. 2005, Hubungan Kesetiaan Pelanggan dan Kualitas Relasi Terhadap Kualitas Jasa. Journal Management.12/4,pp212-216.

Roos, Inger., Anders Gustafsson and Bo Edvardsson. 2006. Defining relationship quality for customer-driven business development A housing-mortgage company case. International Journal of Service Industry Management Vol. 17 No. 2, 2006 pp. 207 -223 Emerald Group Publishing Limited 0956-4233

DOI 10.1108/09564230610657006.

Simpson, Eric, Phillip. 2006. Examining Employee Satisfaction, Customer Service And Customer Satisfaction In A Retail Banking Organization : Dissertation Prepared For The Degree Of Doctor Of Philosophy University Of North Texas.

Singarimbun, Masri, Sofian Effendi. 2005. Metode Penelitian Survei. Pustaka LP3ES. Indonesia.

Tjiptono, Fandi. 2008. Manajemen Pemasaran Jasa. Edisi III. Andi Offset: Yogyakarta.

Tjiptono, Fandi dan Gregorius Candra. 2005. Service, Quality, and Satisfaction. Andi Offset: Yogyakarta.

Widjaja, Bernand T. 2009. Lifestyle Marketing. PT. Gramedia Pustaka Utama, Jakarta.

Zeithaml and Bitner. 2000. Service Marketing Integrating Customer Accross the Firm $2^{\text {nd }}$. Boston: Mc Graw Hill. 